\title{
EFFICACY OF SEED WASHING WITH WATER AND TREATMENT WITH GARLIC EXTRACT AND CARBENDAZIM FOR REDUCING SEED-BORNE FUNGAL PATHOGENS FROM RICE VARIETY KALIJIRA
}

\author{
M. S. I. Uzzal ${ }^{1}$, M. S. Islam ${ }^{1}$, K. Mallick ${ }^{1}$ and M. S. Monjil ${ }^{2 *}$ \\ Department of Plant Pathology, Bangladesh Agricultural University \\ Mymensingh-2202, Bangladesh
}

\begin{abstract}
S
Seed health of aromatic rice variety Kalijira collected from Mymensingh Sadar Upazilla was studied following standard blotter method. Six different treatments namely water wash, garlic $(1: 1)$, water wash + garlic $(1: 1)$, Knowin 50WP (Carbendazim) @ 0.2\% and water wash + Knowin-50WP @ 0.2\% were used in this experiment. The identified seed-borne fungi were Alternaria padwickii, Aspergillus niger, Aspergillus flavus, Bipolaris oryzae, Curvularia lunata, Fusarium moniliforme, Fusarium oxysporum and Penicillium sp. Highest seed infection (30.67\%) was recorded for F. oxysporum and the lowest seed infection (9.33\%) was recorded for $A$. padwickii. Germination of seeds significantly varied in different treatments that ranged from 85.33 to $98.86 \%$. Among the treatments, the highest $(98.86 \%)$ germination was found by water wash + Knowin-50WP and lowest $(85.33 \%)$ by control (untreated). After washing of seeds in water, the treated seeds with plant extract or chemical showing better performance than when only treated with plant extract or chemical for controlling seed borne pathogens.
\end{abstract}

Key Words: Rice, Kalijira, Seed-borne fungi, Washing with water, Garlic

\section{INTRODUCTION}

Rice is the main crop of Bangladesh, which covers about 80 percent of the total cultivable land (BBS, 2010). The average world yield of rice is $3.84 \mathrm{t} \mathrm{ha}^{-1}$ (FAO, 2007), but the average yield of rice in Bangladesh is only $1.507 \mathrm{t} \mathrm{ha}^{-1}$ (BBS, 2010). Moreover, the yield of aromatic rice grown in Bangladesh is lower than non-aromatic rice. Unfortunately, the aromatic rice often has undesirable agronomic characters, such as low yield, susceptibility to diseases and strong shedding (Berner and Hoff, 1986). Kabir et al. (2004) reported that aromatic rice variety Chinigura-1 produced the highest grain yield $\left(2.47 \mathrm{t} \mathrm{ha}^{-1}\right)$ followed by Kalijira $(2.15 \mathrm{t}$ $\left.\mathrm{ha}^{-1}\right)$ and Begunbitchi $\left(0.92 \mathrm{tha}^{-1}\right)$. Because aromatic rice yield is very low as well as diseases and pest are considered as major constrains for aromatic rice production.

\footnotetext{
${ }^{1}$ MS Student and ${ }^{2}$ Associate Professor, Department of Plant Pathology, Bangladesh Agricultural University, Mymensingh-2202, Bangladesh

*Corresponding author
} 
In Bangladesh, 43 diseases are known to occur on the rice crop and among these diseases 27 are seed-borne of which 14 are major (Fakir, 2002). He also reported that fungi are the principal organisms associated with seeds in storage and all the seed-borne diseases of rice. Fungi associated with discolored rice seed resulted in poor germination and vigor, and cause diseases to emerged seedling or growing plants (Danquah et al., 1976 and Sharma et al., 1987).

There is a need to increase the yield and improve the health and seed quality of the crop by controlling seed-borne fungal pathogens. Treatments of seed should be done as a routine practice as it is a cheap insurance against possible disasters at a later stage (Bilgrami and Dube, 1976). Various methods have been practiced to control these pathogens. Use of plant extracts against plant disease control is one of them. To ensure eco-friendly disease management, plant extracts are using instead of hazardous chemicals. Successful use of plant extracts in controlling fungal pathogens has been demonstrated by a number of authors (Assadi and Behroozin, 1987; Miah et al., 1990; Ashrafuzzaman and Khan, 1992; Hossain and Schlosser 1993 and Suratuzzaman et al., 1994).

In view of the above facts, the present study was undertaken to know the efficacy of seed washing with water and treatment with garlic extract and Carbendazim for reducing seedborne fungal pathogens.

\section{MATERIALS AND METHODS}

Farmer's seeds of rice variety Kalijira were collected from Mymensingh Sadar Upazila of Mymensingh district. The seeds were then kept in brown paper bags and stored in the refrigerator at $4^{\circ} \mathrm{C}$ in Seed Pathology Center (BAU) until use. The experiment was conducted during the period from January 2012 to May, 2013 at Seed Pathology Center (SPC), Plant Disease Clinic and M. S. Laboratory, Department of Plant pathology, Bangladesh Agricultural University (BAU), Mymensingh. For the experiment seeds were treated with water, garlic extracts and fungicides. The treatments were $T_{1}=$ Water wash, $T_{2}$ $=$ Garlic extract $(1: 1), \mathrm{T}_{3}=$ Water wash + garlic extract $(1: 1), \mathrm{T}_{4}=$ Knowin $50 \mathrm{WP}$ (Carbendazim) @ 0.2\%, $\mathrm{T}_{5}=$ Water wash + Knowin $50 \mathrm{WP} @ 0.2 \%$ and $\mathrm{T}_{6}=$ control (untreated). Garlic extract was prepared by using the method described by Hossain et al. (1997). For water wash, $5 \mathrm{~g}$ of seeds were washed with running tap water properly and then dried in open air for $5 \mathrm{hrs}$. Seed treatment with garlic extracts was done by dipping seeds in previously prepared garlic extracts (1: 1) for 20 minutes. Required amount of Knowin 50 WP was used for a seed treating at the rate of $0.2 \%$ of seed weight. The treated and untreated seeds were tested for seed-borne fungi following the standard blotter method (ISTA, 1999). Four replications were conducted for each sample. After incubations, the germination of seeds and yielded fungi were counted following the keys outlined by Ramnath et al. (1970), and Khan and Islam (1975). For proper identification of fungi temporary slides were prepared from the fungal colony and observed under a compound microscope and identified with the help of keys suggested by Malone and Muskette (1964); Booth (1971); Ellis (1971), Neergaard (1979) and Mathur and Kongsdal (1994). 
The treated Kalijira rice seeds were sown in trays containing sands for vigour test. After 10 days of sowing, shoot length and root length were measured and seedling vigor was calculated as vigor index following the formula given by Baki and Anderson (1972). The collected all data were analyzed following computer package MSTAT-C and mean differences among the treatments were compared by Duncan's Multiple Range Test (DMRT).

\section{RESULTS AND DISCUSSION}

The incidence of major seed-borne fungal pathogens associated with Kalijira were analyzed and presented in the Table 1. In total eight fungi were detected in all samples of seeds under control condition (non-treated). The identified fungi were Alternaria padwickii, Aspergillus niger, Aspergillus flavus, Bipolaris oryzae, Curvularia lunata, Fusarium moniliforme, Fusarium oxysporum and Penicillium sp. Highest seed infection (30.67\%) of F. oxysporum followed by $F$. moniliforme (24.00\%), Penicillium sp. (17.33\%), B. oryzae (17.33\%), C. lunata $(12.00 \%)$, A. niger (10.67\%), A. flavus (9.43\%). The lowest seed infection was recorded by A. padwickii (9.33\%). Fakir (2000) reported some important pathogenic fungi viz. A. padwickii, Fusarium spp., B. oryzae, P. oryzae and Sarocladium oryzae in rice seed samples collected from three different locations in Bangladesh. Another researcher Nahar (2003) found B. oryzae, F. oxysporum, F. moniliforme, Trichoconis padwickii, Alternaria tenuis and C. lunata in farmers stored rice seeds. The association of seed-borne fungi of rice also have been reported by a good number of researchers (Shrestha et al., 1977; Mia and Mathur 1983; Mendoza and Molina 1980; Ahmed et al. 1989; Agarwal et al., 1990 and Purushattam et al., 1996).

Table 1. Effect of different treatments on germination and seed-borne fungi of rice seeds var. Kalijira

\begin{tabular}{|c|c|c|c|c|c|c|c|c|}
\hline \multirow[t]{2}{*}{ Treatments } & \multicolumn{8}{|c|}{ Percent (\%) seed borne infection } \\
\hline & $\begin{array}{l}\text { Alternaria } \\
\text { padwickii }\end{array}$ & $\begin{array}{c}\text { Aspergillus } \\
\text { niger }\end{array}$ & $\begin{array}{l}\text { Aspergillus } \\
\text { flavus }\end{array}$ & $\begin{array}{c}\text { Bipolaris } \\
\text { oryzae }\end{array}$ & $\begin{array}{c}\text { Curvularia } \\
\text { lunata }\end{array}$ & $\begin{array}{c}\text { Fusarium } \\
\text { moniliforme }\end{array}$ & $\begin{array}{c}\text { Fusarium } \\
\text { oxysporum }\end{array}$ & $\begin{array}{c}\text { penicillium } \\
\text { sp. }\end{array}$ \\
\hline $\mathrm{T}_{1}$ & $9.330^{a}$ & $8.000^{\mathrm{b}}$ & $8.000^{\mathrm{b}}$ & $10.67^{b}$ & $9.330^{\mathrm{b}}$ & $22.67^{b}$ & $25.33^{\mathrm{b}}$ & $10.67^{b}$ \\
\hline $\mathrm{T}_{2}$ & $7.000^{\mathrm{b}}$ & $8.000^{\mathrm{b}}$ & $7.670^{\mathrm{b}}$ & $10.67 \mathrm{~b}$ & $6.670^{c}$ & $17.33^{c}$ & $22.67 \mathrm{c}$ & $9.330 c$ \\
\hline $\mathrm{T}_{3}$ & $5.330^{c}$ & $6.670^{c}$ & $5.330^{c}$ & $8.000^{\mathrm{d}}$ & $5.330^{\mathrm{d}}$ & $9.330^{\mathrm{e}}$ & $12.00 \mathrm{e}$ & $9.330^{c}$ \\
\hline $\mathrm{T}_{4}$ & $5.330^{c}$ & $8.000^{\mathrm{b}}$ & $5.330^{c}$ & $9.330^{c}$ & $5.330^{\mathrm{d}}$ & $10.67^{\mathrm{d}}$ & $18.67^{\mathrm{d}}$ & $9.330^{c}$ \\
\hline $\mathrm{T}_{5}$ & $2.670^{\mathrm{d}}$ & $5.330^{\mathrm{d}}$ & $5.330^{c}$ & $5.330^{\mathrm{e}}$ & $5.330^{\mathrm{d}}$ & $9.330^{\mathrm{e}}$ & $12.00^{\mathrm{e}}$ & $8.000^{\mathrm{d}}$ \\
\hline $\mathrm{T}_{6}$ & $9.330^{\mathrm{a}}$ & $10.67 \mathrm{a}$ & $9.330^{\mathrm{a}}$ & 17.33 a & $12.00^{a}$ & $24.00^{a}$ & $30.67^{a}$ & $17.33^{a}$ \\
\hline $\mathrm{LSD}_{0.05}$ & 0.803 & 0.521 & 1.18 & 0.785 & 0.964 & 0.963 & 1.92 & 1.23 \\
\hline $\begin{array}{l}\text { Level of } \\
\text { significant }\end{array}$ & * & * & * & * & * & * & * & * \\
\hline $\mathrm{CV}(\%)$ & 6.77 & 3.76 & 9.74 & 4.33 & 7.40 & 3.48 & 5.37 & 6.51 \\
\hline
\end{tabular}

* = Significance at 5\% level. Data were subjected to Duncan's Multiple Range Test (DMRT). Each value represents the mean and std deviation of three replications. In a column, figures with same letter or without letter do not differ significantly whereas figures with dissimilar letter differ significantly. $\mathrm{T}_{1}=$ Water wash, $\mathrm{T}_{2}=$ Garlic extract (1:1), $\mathrm{T}_{3}=$ Water wash + Garlic extract, $\mathrm{T}_{4}=$ Knowin $50 \mathrm{WP}, \mathrm{T}_{5}=$ Water wash + Knowin 50WP and $\mathrm{T}_{6}=$ Control (non-treated) 
Table 2. Effect of different treatments on shoot length, root length and vigor index of seedlings

\begin{tabular}{l|c|c|c|c}
\hline \multicolumn{1}{c|}{ Treatments } & Shoot length $(\mathrm{cm})$ & Root length $(\mathrm{cm})$ & Total length $(\mathrm{cm})$ & Vigor index \\
\hline $\mathrm{T}_{0}$ & $9.100^{\mathrm{d}}$ & $8.380^{\mathrm{d}}$ & $17.48^{\mathrm{d}}$ & 1442.1 \\
$\mathrm{~T}_{1}$ & $10.10^{\mathrm{c}}$ & $8.620^{\mathrm{d}}$ & $18.72^{\mathrm{c}}$ & 1572.8 \\
$\mathrm{~T}_{2}$ & $10.18^{\mathrm{c}}$ & $9.260^{\mathrm{c}}$ & $19.44^{\mathrm{bc}}$ & 1652.4 \\
$\mathrm{~T}_{3}$ & $11.36^{\mathrm{b}}$ & $11.80^{\mathrm{a}}$ & $23.16^{\mathrm{b}}$ & 2048 \\
$\mathrm{~T}_{4}$ & $10.62^{\mathrm{bc}}$ & $10.66^{\mathrm{b}}$ & $21.28^{\mathrm{bc}}$ & 1830 \\
$\mathrm{~T}_{5}$ & $14.42^{\mathrm{a}}$ & $12.00^{\mathrm{a}}$ & $26.42^{\mathrm{a}}$ & 2443.85 \\
\hline LSD $_{0.05}$ & 0.964 & 0.598 & 2.91 & \\
\hline Level of significant & $*$ & $*$ & $*$ & \\
\hline CV $(\%)$ & 4.95 & 3.32 & 7.77 & \\
\hline
\end{tabular}

$\mathrm{T}_{1}=$ Water wash, $\mathrm{T}_{2}=$ Garlic extract $(1: 1), \mathrm{T}_{3}=$ Water wash + Garlic extract, $\mathrm{T}_{4}=$ Knowin $50 \mathrm{WP}, \mathrm{T}_{5}=$ Water wash + Knowin 50WP and $\mathrm{T}_{6}=$ Control (non-treated)

The highest seed-borne infection of A. padwickii was recorded in untreated control (9.33\%). Best control was achieved by Water wash + Knowin 50 WP $(2.67 \%)$, while Water wash, Garlic extract $(1: 1)$, Water wash + garlic extract $(1: 1)$ and Knowin 50 WP showed 9.33\%, $7.00 \%, 5.33 \%$, and $5.33 \%$ infection respectively.

The highest seed-borne infection of all other detected fungi was found in untreated control $\left(\mathrm{T}_{6}\right)$. The lowest seed-borne infection of A. niger was recorded in Water wash + Knowin 50 WP $(5.33 \%)$ treatment, where as the lowest seed-borne infection of A. flavus was recorded in Water wash + garlic extracts, Knowin $50 \mathrm{WP}$ and Water wash + Knowin $50 \mathrm{WP}(5.33 \%)$ treatment. The lowest infection of B. oryzae was recorded in $T_{5}(5.33 \%)$ followed by Water wash + garlic extracts $(8.00 \%)$. Best control of C. lunata was achieved by Water wash + garlic extracts, Knowin 50 WP and Water wash + Knowin 50 WP treatments $(5.333 \%)$ followed by Garlic extracts. The lowest seed-borne infection of F. oxysporum and F. moniliforme was observed by Water wash + Knowin 50 WP followed by Water wash + garlic extracts treatment. The lowest infection of Penicillium sp. was recorded by Water wash + Knowin 50 WP $(8.0 \%)$. Garlic extracts, Water wash + garlic extracts, Knowin 50 WP showed similar results $(9.33 \%)$ and these are statistically similar.

Using tray sand method, highest percentage of germination was observed by Water wash + Knowin 50 WP (92.5\%) and lowest percentage of germination was observed by untreated control (Fig. 1). In control treatment mean shoot length was $9.1 \mathrm{~cm}$, mean root length was $9.26 \mathrm{~cm}$ and vigor index was $1468.8 \mathrm{~cm}$, whereas after treatment the highest mean of shoot length was $14.42 \mathrm{~cm}$ and highest root length was $11.80 \mathrm{~cm}$ as well as highest vigor index was $2443.85 \mathrm{~cm}$ were found by Water wash + Knowin 50 WP. Roos and Puhl (1994) reported that fungal diseases caused by Fusarium and Helminthosporium can be controlled by seed treatment before sowing. Kabir et al. (2007) reported that farmer's stored wheat seeds washed with water or brine solution increase seed germination and suppressed the 
incidence of Bipolaris sorokiniana. Hasan (2000) reported that rice seeds become free from Bipolaris oryzae when washed with brine solution. Panna et al. (2009) reported reduced fungal association in seeds washed with brine solution. From these results and discussion, it can be conclude that after water washing of seeds with normal water followed by treating with plant extract or chemical it give the better result than when only treated with plant extract or chemical.

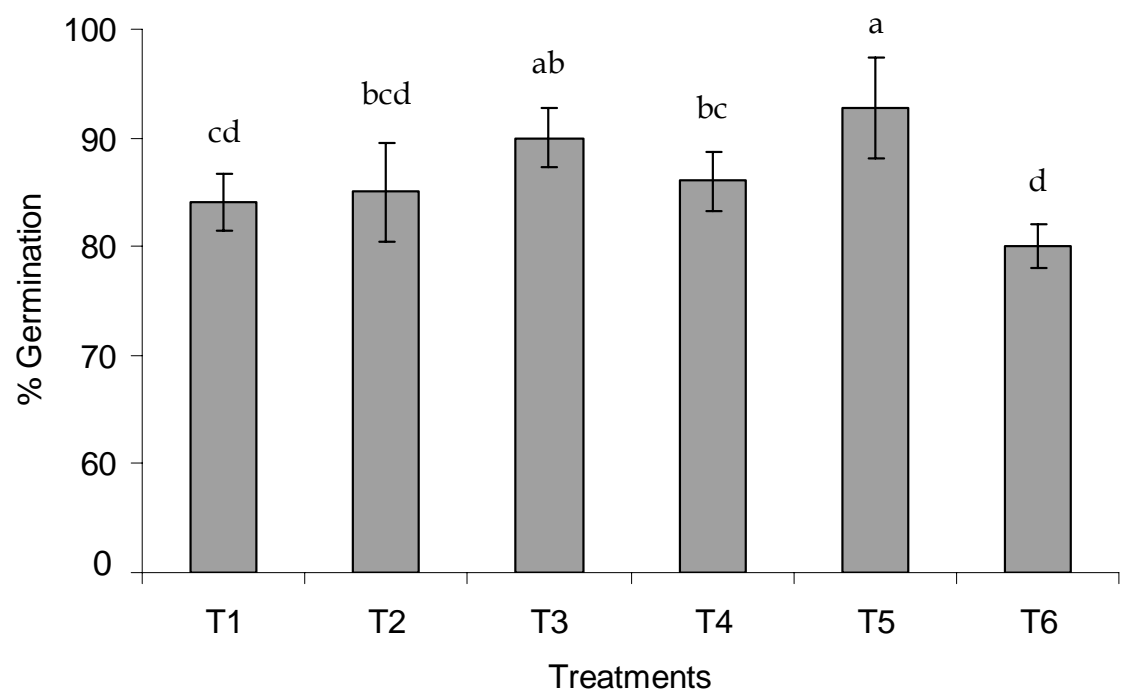

$\mathrm{T}_{1}=$ Water wash, $\mathrm{T}_{2}=$ Garlic extract $(1: 1), \mathrm{T}_{3}=$ Water wash + Garlic extract, $\mathrm{T}_{4}=$ Knowin $50 \mathrm{WP}, \mathrm{T}_{5}=$ Water wash + Knowin 50WP and $\mathrm{T}_{6}=$ Control (non-treated)

Fig. 1. Effect of different treatments on seed germination (\%) of rice variety Kalijira. Data were subjected to Duncan's New Multiple Range Test (DMRT) using MSTAT-C. Each value represent the mean and standard deviation of three replication. In a column figure with same letter or without letter do not prefer significantly where as figure dissimilar letter differ significantly

\section{REFERENCES}

Agarwal, D. C., Mortensen, C. N. and Mathur, S. B. 1990: Seed-borne diseases and seed health testing of rice. Phytopathological Papers., 30: 106. [Rice Abstr., 1990. 13(5): 274].

Ahmed, S. N., Siddique, N. V. and Khan, M. Q. 1989. Seed-borne fungi associated with seed lots of different paddy cultivars in Pakistan. Pak J. Bot., 21(2): 309.

Ashrafuzzaman, M. H. and A. R. Khan. 1992. Antifungal activity in vitro of some plant extract on Rhizoctonia solani. Bangladesh J. Sci. Res., 10(2): 243-244.

Assadi, P. and Behroozin, M. 1987. The effect of bulb extracts of onion and garlic on the mycelial growth of Fusarium spp., Sclerotium cepivorun. Iran. J. Plant Path., 23(1-4): 1-3.

Baki, A. A. and Anderson, J. D. 1972. Physiological \& biological deterioration of seeds. In seed Biology, Vol. 11. Academic Press, New York. pp. 283-315. 
BBS 2010. Statistical Year Book of Bangladesh, Bangladesh Bureau of Statistics, Statistics Division, Ministry of planning, Government of People's Republic of Bangladesh, Dhaka.

Bemer, D. K., Hoff, B. J. 1986. Inheritance of scent in American long grain rice. Food Sci. E Tech., 26: 876-878.

Bilgrami, K. S., Dube, H. C. 1976: A Text Book of Modern Plant Pathology. Vikas Publishing House PVT, Ltd. New Delhi. pp. 164.

Booth, C. 1971. The genus Fusarium Commonwealth Mycol. Inst. Kew, Surrey, England. pp. 236.

Danquah, O. A., Mathur, S. B. and Neergaard, P. 1976. Fungi associated with discoloured rice seeds in Ghana. Ghana J. Agric. Sci., 9(3): 185-187.

Ellis, M. B. 1971: Dematiaccous Hypomycetes. CMI, Kew, Surrey, England. pp. 507.

Fakir, G. A. 2000. An annotated list of seed-borne disease in Bangladesh. Seed Pathology Laboratory. Dept. of Plant Pathology, BAU, Mymensingh. pp. 41.

Fakir, G. A. 2002. An annotated list of seed-borne disease in Bangladesh. Seed Pathology Centre, Department of Plant Pathology, Bangladesh Agricultural University, Mymensingh. pp. 39

FAO 2007. Production year Book. Food and Agriculture organization. Rome, Italy.

Hasan, M. M. 2000. Effect of seed cleaning and washing on germination, disease incidence and yield of rice BR-11 (Mukta), M. S. Thesis, Department of Plant Pathology, Bangladesh Agricultural University, Mymensingh.

Hossain, I. and Schlosser, E. 1993: Control of Bipolaris sorokiniana in wheat with neem extracts. Bangladesh J. Microbiol., 10(1): 39-42.

Hossain, I., Mahamud, H. and Ashrafuzzaman, H. 1997. Effects of plant extracts on fungi (Bipolaris sorokiniana and Rhizoctonia solani) and okra mosaic disease. Ecoprint, 4(1): 35-42.

International Seed Testing Association (ISTA), 1999. International Rules for Seed Testing. Seed Sci. and Technol., 23: 269.

Kabir, M. H., Aminuzzaman, F. M., Islam M. R. and Chowdhury M. S. M. 2007. Effect of physical and chemical seed treatments on leaf spot (Bipolaris sorokiniana) and yield of wheat. World J. Agric. Sci., 3(3): 306-315.

Kabir, M. E., Kabir, M. R., Jahan, M. S. and Das, G. G. 2004. Yield Performance of Three Aromatic Fine Rices in a Coastal Medium High Land. Asian J. Plant Sci.., 3: 561-563.

Khan, M. H. and Hossain, I. 1993: Antifungal activity of crude plant extracts against Bipolaris sorokiniana. Paper presented at 5th Biennial Conference of Bangladesh Phytopathological Society, 27-28 June, 1993. BAU, Mymensingh. pp. 10.

Khan, A. Z. M. and Islam, N. A. S. 1975. Colletotrichum lindeinuthianum of Dolichos lablab from Bangladesh. Bangladesh J. Bot., 4(1-2): 121-123.

Legaspi, A. G., Marcado, A. and Ventura, A. 1985. Survey and identification of seed-borne fungi of rice in region. Phil. Phytopath., 21(1-2): 5.

Malone, G. P., Muskette, A. E. 1964: Seed-borne fungi Description of 77 fungal species. Proc. Intl. Seed Test Ass., 29(2): 180-183.

Mathur, S. B. and Kongsdal, O. 1994. Seed mycology. Description and Illustrations of fungi. DGISP for Developing, Denmark, $1^{\text {st }}$ edn. 
Mathur, S. B., Nghiep, H. V. and Du, P. V. 2001. Effect of cleaning on seed health and seed germination of rice. Omonrice., 9: 138-139.

Mendoza, A. M. and Molina, R. P. 1980. A study on seed-borne fungi associated with rice seed and their effects on rice seedlings. J. Araneta Res., 27(14): 50-69.

Mia, M. A. T. and Mathur, S. B. 1983. Study on seed mycoflora of rice in Bangladesh. Seed Res., 11(2): 254-257.

Miah, A. T., Ahmed, M. U., Sharma, N. R., Ali, A. and Miah, S. A. 1990. Antifungal activity of some plant extracts. Bangladesh J. Bot., 19(1): 5-20.

Nahar, K. 2003. Seed quality and seedling health of farmer's rice of Bogra district. M.S. Thesis, Department of Plant Pathology, BAU, Mymensingh. pp. 77-78.

Neergaard, P. 1979. Seed Pathology. Vol. 1. The Macmillan Press Ltd. pp. 839.

Panna, R., Aminuzzaman, F. M., Islam, M. R. and Bhuyan, M. H. M. B. 2009. Evaluation of Some Indigenous Plant Extracts for Suppressing Bipolaris Sorokiniana in Wheat Seed. The Agriculturists 7(1): 96-104.

Purushottam, S. P., Patkar, H. S. and Shetty, H. S. 1996: Storage fungi and their influence on rice seed quality. Indian Phytopathol., 49(2): 152-156.

Ramnath., Mathur, S. B. and Neergaard, P. 1970. Seed-borne fungi of mungbean (Phaseolus aureus Roxb.) from India and their significance. Proc. Int. Seed Test Assoc., 35: 225-241.

Roos, H. and Puhl, T. 1994. Seed dressing obsolete routine treatment or the basis of economic grain cultivation. Gesunde Pflanzen., 46(6): 212-214.

Sharma, H. L., Randhawa, H. S., Kapur, A. and Singh, S. 1987. Seed discolouration in rice. Oryza., 24(1): 37-41.

Shrestha, S. K., Mathur, S. B. and Neergard, P. 1977. Seed-borne disease in some crops of Nepal. Seed Sci. \& Technol., 5(1): 111-121.

Suratuzzaman, M., Hossain, I. and Fakir, G. A. 1994. Control of seed-borne fungi of two rice varieties with some plant extracts. Progress. Agric., 5(1): 1-5. 